\title{
ROBOT SEBAGAI SUMBER INSPIRASI PENCIPTAAN KARYA SENI DIGITAL PAINTING
}

\author{
Egi Sofiandika \\ Seni Rupa Murni, Fakultas Seni Rupa dan Desain \\ Universitas Sebelas Maret \\ JI. Ir. Sutami No. 36A Kentingan, Jebres, Surakarta, 57126 \\ Email: egisofiandika@ricketmail.com \\ Narsen Afatara \\ Fakultas Seni Rupa dan Desain \\ Universitas Sebelas Maret
}

\begin{abstract}
ABSTRAK
Tugas Akhir ini menginterpretasikan gagasan imajinasi penulis dalam judul Robot Sebagai Sumber Inspirasi Penciptaan Karya Seni Digital Painting, yaitu robot sebagai tema utama. Terdapat beberapa permasalahan yang dibahas dalam Tugas Akhir ini, yaitu; 1) apa yang dimaksud dengan robot sebagai tema pembuatan karya seni, 2) mengapa teknik digital painting digunakan dalam pembuatan karya seni yang bertemakan robot, 3) bagaimana memvisualisasikan robot kedalam karya seni digital painting. Robot diciptakan guna memenuhi kebutuhan kosumen, ada pun jenisnya; robot mobile, robot manipulator, robot humanoid, flying robot, robot berkaki, robot animalia, robot cyborg. Perkembangan teknologi robot meledak begitu pesatnya seakan-akan tidak ada ujungnya. Tahun demi tahun perusahan yang berbasis teknologi berlomba-lomba dalam menciptakan teknologi robotnya terlihat seperti ajang pamer untuk menunjukan siapa yang lebih unggul dalam menciptakan. Penulis tertarik mengambil tema tersebut, di karenakan penulis beranggapan bahwa robot merupakan teknolgi yang misterius dan ingin memaparkan sudut pandangnya tentang gambaran robot. Tujuan dari penulis ialah mendiskripsikan perkembangan teknologi bebasis robot, serta berharap karya lukis digital painting dapat menjadi masukan bagi ilmu pengetahuan terutama di bidang seni. Metode Penciptaan melalui penggalian ide dari pengamatan dan sebuah perenungan berdasarkan sumber yang di dapat, dan hasil pengamatan di konsep melalui rancangan sketsa yang ditata berdasarkan asas keseni rupaan, tahapan terakhir ialah, memindahkan ide yang terkonsep menjadi gambar yang di buat sedemikian rupa dengan menggunakan teknik digital painting. Hasil karya yang diolah melalui pendekatan simbolisme visual yang bersifat komunikatif dan umum, yang dikemas secara estetik, diharapkan penikmat tertarik, terhiburan dan paham untuk melihat apa yang disampaikan oleh karya lukis serta pesan moral yang terkandung di dalamnya.
\end{abstract}

Kata kunci: robot, digital painting, seni lukis.

\begin{abstract}
This Final Project interprets the idea of the author's imagination in the title "Robot Sebagai Sumber Inspirasi Penciptaan Karya Seni Digital Painting", namely robots as the main theme. There are several problems discussed in this final project, namely: 1) what is meant by robots as the theme of making artworks, 2) why digital painting techniques are used in making robot-themed artworks, and 3) how to visualize robots into digital painting artwork. Robots are created to meet consumer needs. The types include: mobile robot, manipulator robot, humanoid robot, flying robot, legged robot, animalia robot, andcyborg robot. The development of robotic technology exploded so rapidly as if there was no end. Year after year technology-based companies are competing to create robot technology and it looks like a showroom to show who is superior at creating. The author is interested in the theme because the author assumes that robot is a mysterious technology. The author also wants to expose his perspective on the image of robot. This study aims to describe the development of robot-based technology, and hopes that the works of digital painting can become input to science, especially in the arts. The method of creation is by extracting ideas from observations and contemplation based on the sources obtained, then the observations are conceptualized in concepts through design sketches which are arranged according to the principle of visual arts. The last step is to move the conceptualized idea into an image made by using digital painting techniques. The works that are processed through a communicative and general approach of visual symbolism, which are packed aesthetically, are expected to make the audiences interested, entertained and can see what is conveyed by the paintings and moral messages contained therein.
\end{abstract}

Keywords: robot, digital painting arts, painting. 


\section{GE[AR sumal Sori Bublya}

\section{A. Pengantar}

Robot hanyalah sebuah gagasan atau pikiran hasil ciptaan manusia yang berupa fiksi. Namun setelah dunia memasuki jaman industri, robot sudah ada dan bukan lagi hanya sebuah cerita fiksi dari novelnovel, teater maupun film. Robot mulai diciptakan dan di kembangkan guna memenuhi kebutuhan manusia yang semakin berkembang. Ada pun fungsi robot pada saat itu sebagai alat pembantu seperti penjelejah di laut, di angkasa untuk mendapatkan ilmu atau penemuan baru, dan pembuatan makanan, pencetakan, pengemasan di pabrik. Namun seiring dengan berjalannya waktu robot terus berkembang dan semakin berkembang dan bukan hanya dimanfaatkan untuk kepentingan industri saja sekarang ini robot telah menjadi alat pembantu dalam dunia hiburan maupun dalam kehidupan sehari-hari manusia, sehingga dapat dikatakan hampir setiap manusia memiliki berbagai jenis robot untuk membantu kehidupan sehari-harinya.

Berdasarkan perkembangan teknologi robot inilah akhirnya dijadikan penulis sebagai sumber inspirasi dalam penciptaan karya seni. Dan penulis tertarik menggunakan bentuk robot ke dalam karya lukis dengan Teknik digital painting.

\section{B. Pembahasan}

Robot menurut kamus bahasa berasal dari kata robota yang artinya pekerja, robot dapat di definisikan sebagai sebuah alat mekanik yang dapat bekerja secara terus-menerus untuk membantu pekerjaan manusia, yang dalam menjalankan tugasnya yang dapat dikontrol langsung oleh manusia ataupun bekerja secara otomatis sesuai program yang telah ditanamkan kedalam chip kontroler robot (Sanjaya, 2016:2)

Pertama kali robot muncul dan berkembang di dunia, berasal dari daerah timur tengah, pada abad 13. Pada saat itu insinyur cerdas bernama Al-jazari telah mampu menciptakan berbagai mesin otomatis, yang sekarang dikenal sebagai robot yang bentuknya mirip manusia. Sehingga masyarakat sains modern menjulukinya atau menamainya 'Bapak Robot'. kriteria, yaitu:

Secara umum robot digolongkan menjadi dua

Robot autonomous adalah robot yang dapat bekerja tanpa harus dikontrol secara langsung oleh manusia. Prinsip kerja robot autonomous secara sederhana adalah kemampuan dalam memberikan respon terhadap perubahan kondisi lingkungan, dengan berbagai sensor yang dimiliknya (Sanjaya, 2016:5).
Robot kontrol adalah robot yang harus dikendalikan langsung oleh manusia. Contoh robot jenis ini adalah komputer PC/laptop, telivisi, handphone, robot remote kontrol, dan lainnya (Sanjaya, 2016:5).

Berdasarkan penjelasan tersebut dapat disimpulkan bahwa robot adalah suatu mesin atau alat bantu manusia yang dapat bekerja secara terus menerus.

Tema yang dipilih yaitu bentuk robot sebagai penciptaan karya seni merupakan hasi pemikiran dan pemahan penulis berdasarkan ketertarikan akan teknologi robot.

\section{Proses Kreatif Karya 1)}

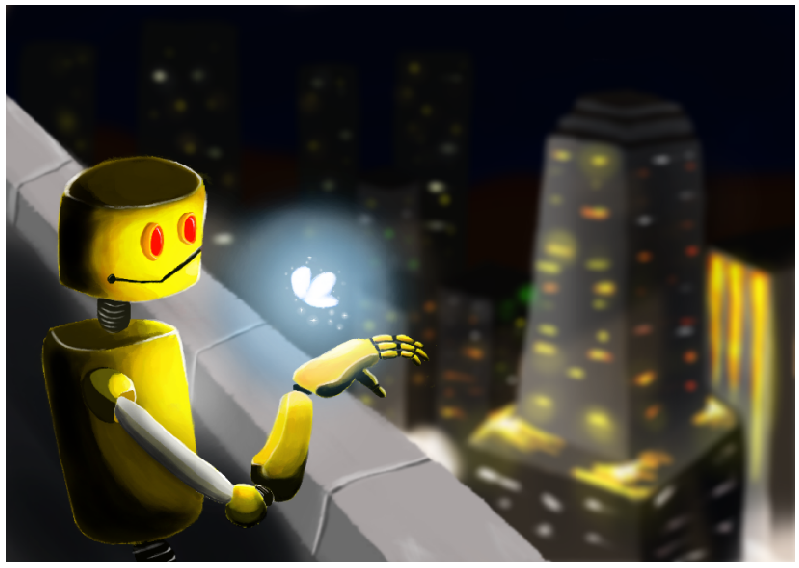

Gambar 1 "im human" (2018), 80 x 60 cm, print on albatros

(Sumber: Egi Sofiandika. 2018)

Robot yang sedang bercengkrama dengan kupu-kupu di malam hari, terlihat robot begitu prihatin dan peduli dengan kupu-kupu tersebut karena habitatnya telah direnggut dan berubah menjadi perkotaan yang padat. Ironisnya, robot itu menganggap dirinya lebih baik dari manusia dalam segala hal, kecerdasan, kemampuan, bahkan perasaan. Dengan pemahaman yang dia tau bahwa manusia merupakan mahluk perusak alam yang selalu menghalalkan berbagai macam cara untuk kepentingannya sendiri.

Karya ini terinspirasi dari dampak perubahan perkembangan industri di era globalisasi, seperti perluasan lahan dengan menebang hutan, pencemaran udara dengan munculnya banyak pabrik-pabrik yang menghasilkan limbah udara dan pencemaran air. Oleh 
karena itu banyak mahluk hidup atau binatang yang mati akibat tempat tinggal atau habitatnya di rusak oleh manusia.

\section{Karya 2)}

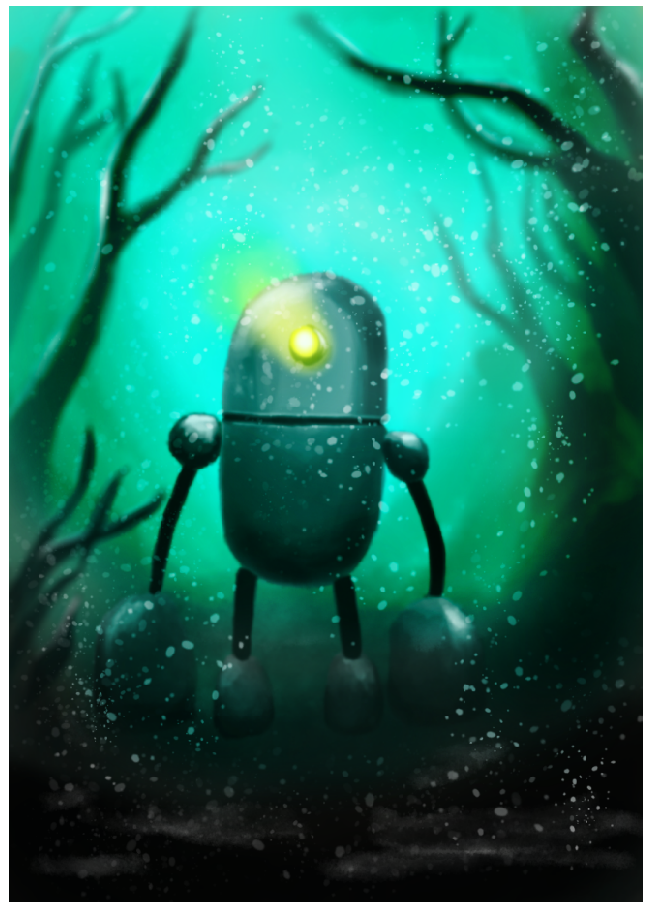

Gambar 2 "lost"(2018), 80 x 60 cm, print on albatros

(Sumber: Egi Sofiandika. 2018)

Sedih, kesendirian, kesengsaraan yang dirasakan karena ditinggalkan, teramat sakit membekas. Hati yang bingung tak tentu arah kian menyiksa setiap langkah yang di ambil, seolah-olah penderitaan yang dialaminya tak ada habisnya. Itu lah perasaan yang digambarkan oleh robot ini setelah dia ditinggalkan dan tersesat tak tau arah tujuan seakanakan semuanya berakhir pada satu titik.

Karya ini terinspirasi dari perasaan yang pernah penulis rasakan, yaitu perasaan sedih akan kesendirian karena di tinggalkan, tak memiliki teman ataupun seorang untuk berbagai cerita merupakan hal paling menyakitkan dalam menjalani kehidupan.

Penggambaran penulis sebagai robot yang sedang gelisah tersesat dalam kegelapan dan sorotan lampu dari matanya seakan-akan mencari jalan keluar dari tampat yang mencekam dan menakutkan itu, ditambah dengan keadaan cuaca yang bersalju dan dingin di maksud untuk semakin menggambarkan suasana betapa mendiritanya robot itu.

\section{Karya 3)}

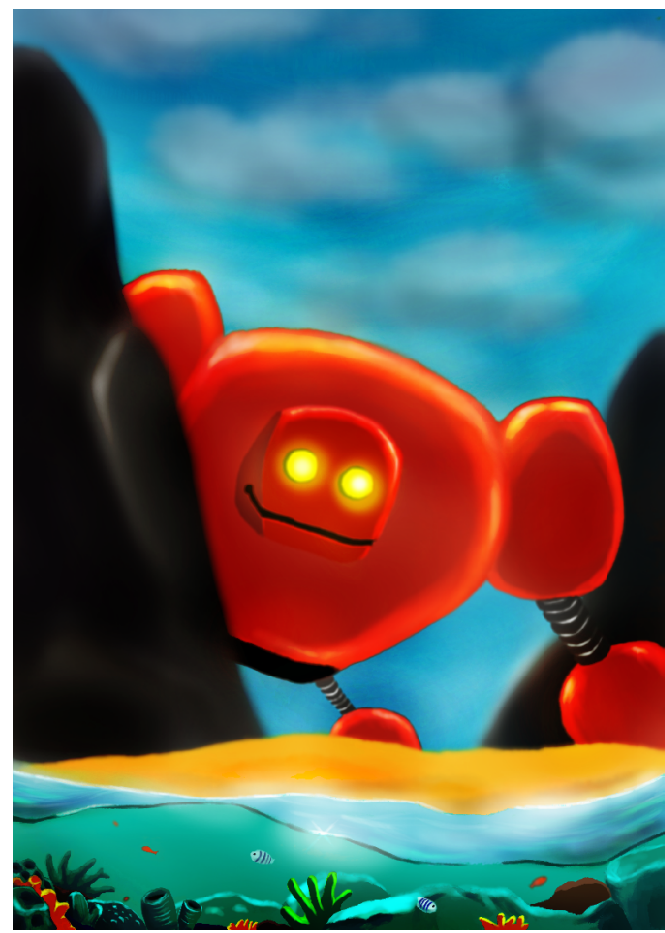

Gambar 3 "hide and seek"(2018), 80 x $60 \mathrm{~cm}$, print on albatros

(Sumber: Egi Sofiandika. 2018)

Hide and Seek dalam bahasa Indonesia dapat diartikan petak umpet. Petak umpet merupakan permainan yang sering di mainkan oleh anak-anak. Maksud permainan ini adalah sembunyi dalam artian seorang harus menemukan teman-temannya yang sedang bersembunyi, atau tidak dia akan terkena hukuman. Permainan ini sangat popular di kalangan anak-anak, hampir semua orang pernah memainkan ini.

Visual menampilkan sebuah robot sedang mencari sesuatu yang tak kunjung ditemukan di pantai, entah apa yang dia cari, dengan ketidakpastian namun dia tetap terus mencari kebahagiaan dan berharap dengan keyakinan suatu saat pasti dapat dia temukan. Pada masa pencariannya di pantai robot tersebut hanya melihat laut dari kejahuan tanpa menyadari keindahan yang ada di dalam laut, jika robot tersebut lebih cepat menyadarinya keindahan terumbu karang sekaligus ekosistem yang ada di dalam laut mungkin dia dapat menemukan kebahagian yang ia cari selama ini. 


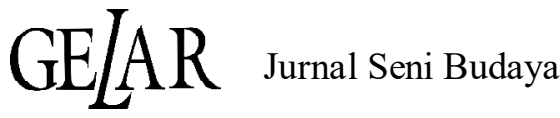

Karya 4)

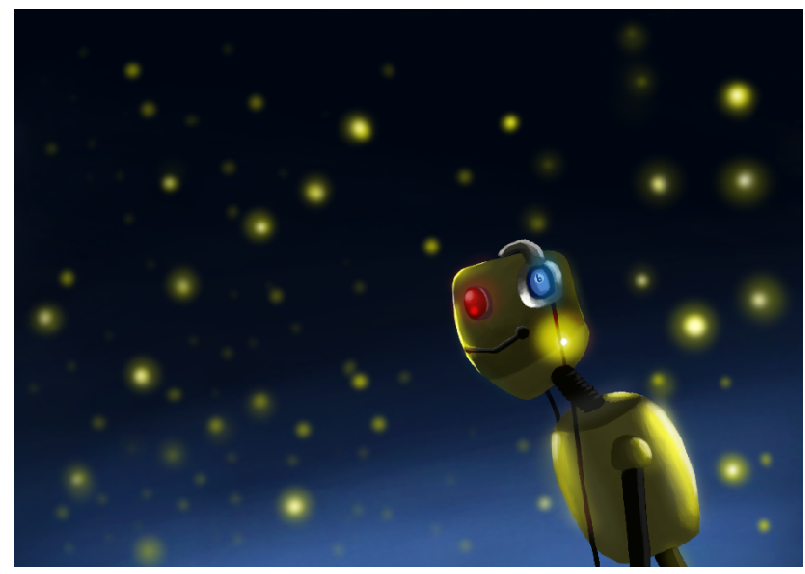

Gambar 4 "alone and firefly"(2018), $80 \times 60 \mathrm{~cm}$, print on albatros (Sumber: Egi Sofiandika. 2018)

Setiap masalah dalam kehidpuan pasti membuat kita lelah ditambah lagi jika masalah terus berdatangan. Ada saatnya manusia benar-benar membutuhkan waktu untuk sendiri, menghibur diri untuk memikirkan semua apa yang telah terjadi lalu merenungkannya, dengan tujuan mengistirahatkan tubuh dan pikiran dari berbagai gangguan sehingga dapat tumbuh menjadi pribadi yang lebih baik lagi.

Menggambarkan robot yang sedang termenung di suatu tempat yang sunyi dengan di temani banyak kunang-kunang, penggambaran pada karya dengan maksud seseorang yang ingin menghilangkan semua kepenatan yang dirasakan. Latarbelakang background menggunakan warna gelap dan dengan dipilihnya kunang-kunang dimaksud guna menambah suasana sunyi dan nyaman pada karya. Alih-alih robot mendengarkan musik dengan headphone dengan maksud menunjukkan suasana hati robot tersebut sedang bahagia.
Karya 5)

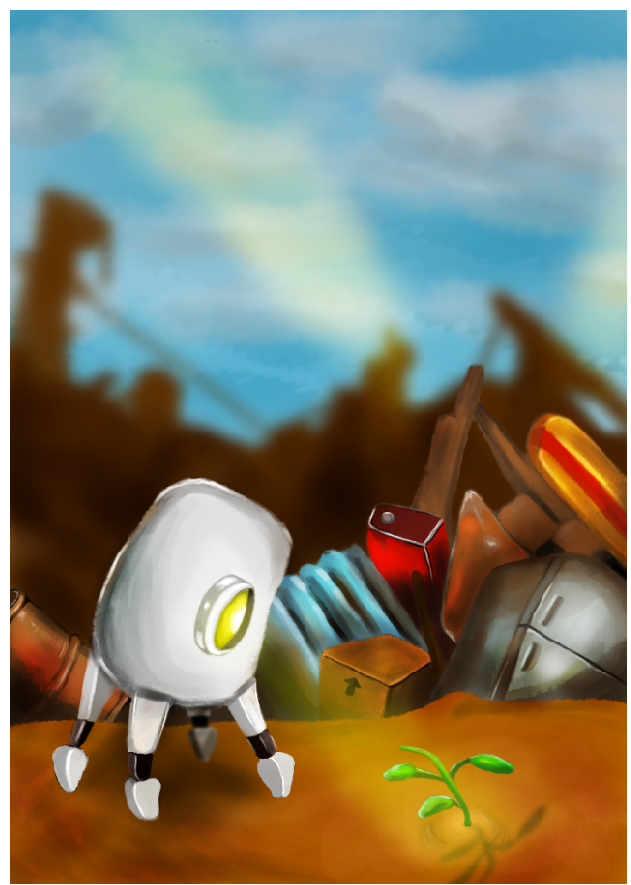

Gambar 5 "new friend"(2018), 80 × 60 cm, print on albatros

(Sumber: Egi Sofiandika. 2018)

Dalam kumuhnya tempat yang tertinggal, terdapat sebuah robot yang menemukan tunas tumbuh, dengan perasaan tak menyangka robot tersebut terheran-heran bagaimana bisa tanaman dapat tumbuh di tempat seperti itu, robot tersebut pun berharap dengan munculnnya tanaman tersebut dapat mengubah tempat itu dan kehidupannya menjadi lebih baik dari sebelumnya.

Karya ini menggambarkan menemukan seorang sahabat di kala kita sedang jatuh merupakan bagai menemukan kebahagiaan, semangat, ataupun harapan baru bagi seseorang, disimbolkan robot yang telah menemukan sebuah tunas yang tumbuh di antara kumuhnya tempat yang tertinggal, seakan-akan itu merupakan hal yang mustahil. Begitu pula menemukan sahabat yang baik dan selalu mendukung merupakan sesuatu yang tidak mudah. Pemilihan background di gambarkan sebagai tempat yang ditinggalkan atau tempat pembuangan sampah dengan maksud menggambarkan perasaan robot tersebut yang sedang sedih dan kesepian. 
Karya 6).

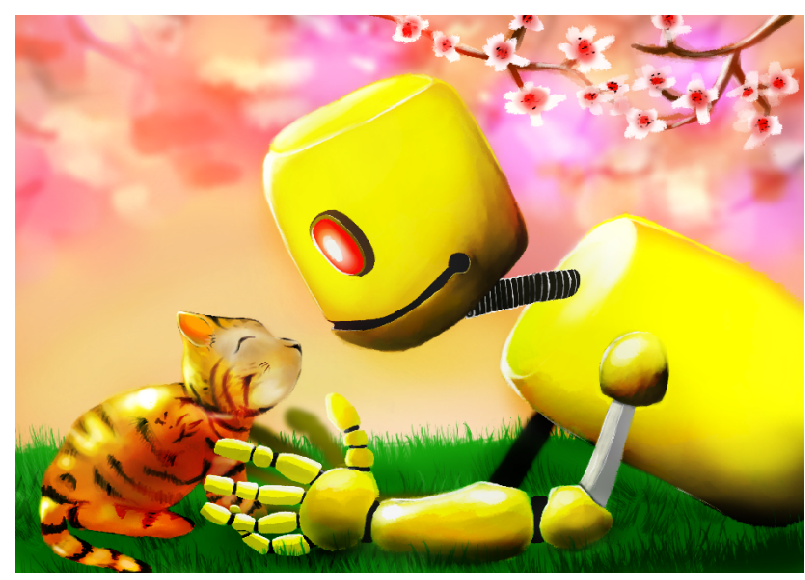

Gambar 6 “my pet" (2018), 80 x 60 cm, print on albatros

(Sumber: Egi Sofiandika. 2018)

Terlihat bahagianya sebuah robot yang sedang asik bermain dan bercengkrama dengan seekor kucing, seakan-akan robot tersebut sedang bercerita dan kucing pun paham dengan apa yang di ceritakan robot, begitupun sebaliknya. Sehingga mereka terlihat saling melengkapi satu sama lain.

Kehidupan setiap manusia pasti memerlukan orang lain untuk memenuhi kebutuhan jasmani ataupun rohani, tidak semua hal bisa kita lakukan sendiri begitu pula teman atau sahabat, kita sebagai mahluk sosial membutuhkan teman baik atau pun tempat untuk berbagi keluh kesah tentang permasalahan yang di hadapi. Namun, tidak semua masalah dapat diceritakan ataupun tidak semua orang dapat mendengarkan masalah kita, di sini hewan peliharaan dapat di jadikan pilihan sebagai pengganti teman curhat tentang masalah yang di hadapi, meskipun mereka tidak mengerti apa yang di bicarakan namun mereka tetap memberikan perhatian pada kita.

\section{Karya 7)}

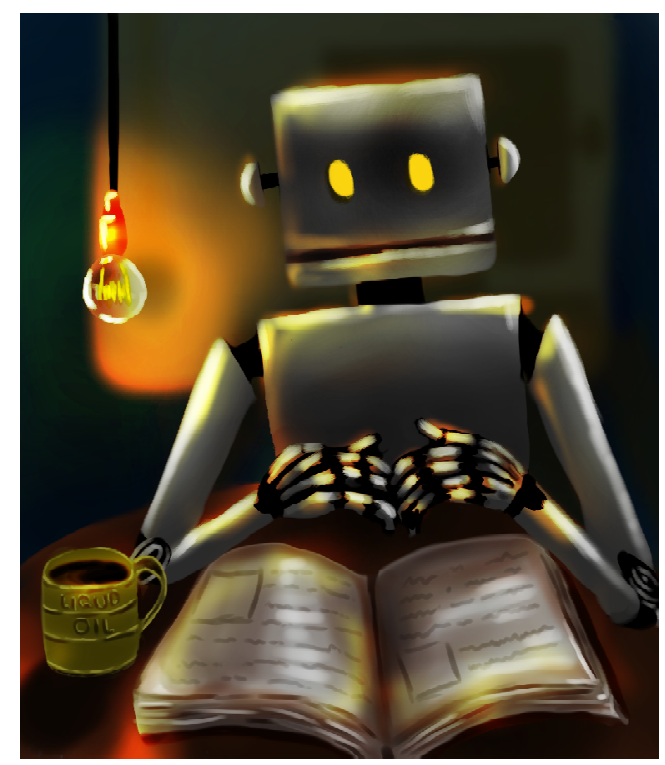

Gambar 7 "light in the dark"(2018), $80 \times 60 \mathrm{~cm}$, print on albatros (Sumber: Egi Sofiandika. 2018)

IImu bagaikan cahaya petunjuk bagi seseorang untuk menerangi jalan di kegelapan atas ketidak tahuan kala seseorang dipersimpangan jalan ilmu akan menunjukan jalan yang tepat. Begitu juga yang di gambarkan robot tersebut yang tak pernah lelah dan kehilangan semangat untuk belajar, karena dia tau bahwa pengetahuan sangat lah penting.

Dalam karya ini diceritakan sebuah robot yang tengah membaca buku. Maksud dari robot tersebut yaitu di umpamakan sebagai manusia yang tengah belajar untuk mendapatkan mimpinya, penulis menambahkan lampu, dan cangkir berisikan oli untuk memunculkan susana dingin dan tenang, sedangkan sebuah buku disimbolkan sebagai ilmu untuk menerangi seseorang ataupun membimbing seseorang untuk menjadi manusia yang berpendidikan. 


\section{GEEAR Jumal Scri Bublya}

Karya 8)

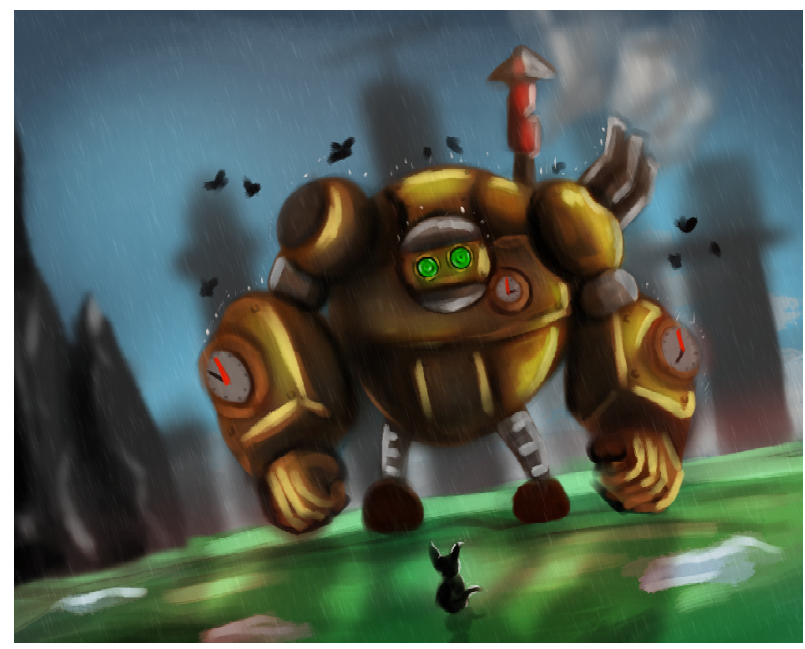

Gambar 8 "nonstop working"(2018),

$80 \times 60 \mathrm{~cm}$, print on albatros

(Sumber: Egi Sofiandika. 2018)

Robot merupakan mesin jenis pekerja yang tak kenal lelah, karena pada dasarnya robot dibuat selalu dengan program ataupun perintah yang hanya bisa berhenti ketika robot tersebut mati ataupun rusak. Sehingga memungkinkan robot untuk terus bekerja tanpa berhenti.

Pada karya ini diceritakan robot yang di umpamakan sebagai sosok manusia yang bekerja tanpa henti dengan disimbolkannya gambar jam pada lengan maupun pada dada robot tersebut. Namun pekerjaan tersebut seakan-akan menjadi bomerang pada kesehatanya dengan di gambarkanya keadaaan robot yang rusak. Sedangkan penggunaan warna dingin dan panas di maksud agar dapat memunculkan suasana tegang dan sedih, terebih lagi di tambahnya cuaca yang sedang hujan pada gambar semakin menambah kesedihan dan keputusasaan pada robot tersebut.

Pekerjaan merupakan suatu hal yang sangat penting bagi manusia, tanpa pekerjaan manusia tak mampu hidup ataupun memenuhi kebutuhannya sehari-hari. Namun tidak seharusnya manusia terusmenerus bekerja tanpa henti karena manusia memiliki kapasitas tubuhnya masing-masing. Jangan sampai pekerjaan dapat menyebabkan kesehatan terganggu dan menimbulkan penyakit.

\section{Kesimpulan}

Penulisan tugas akhir ini, menganggap perkembangan teknologi di bidang robot memiliki dampak perubahan yang sangat besar pada kehidupan manusia. Tidak bisa di pungkiri lagi bahwa manusia tak bisa lepas dari bantuan robot, yang pada awalnya robot hanya terdapat di bidang industri sekarang robot sudah merambah masuk ke dalam kehidupan sehari-hari manusia.

Proses kreatif dalam menuangkan tema bentuk robot sebagai sumber inspirasi pembuatan karya seni di karenakan ide penulis yang muncul berdasarkan pengamatan dan pemahaman yang di dapat kan penulis akan perubahan perkembangan teknologi robot yang penulis lihat selama ini. Sehingga dari ide tersebut penulis penulis berhasil menyimpulkan gambaran "bentuk robot" menurut imajinasi penulis yang pada akhirnya tertuang pada karya seni berjenis digital painting.

\section{KEPUSTAKAAN}

Anna Bentkowska-Kafel, Trish Cashen, dan Hazel Gardiner. 2015. Digital Art History: A Subject in Transition. USA: Intellect.

Brinkmann, Ron. 1999. The Art and Science of Digital Compositing. USA: Elsevier.

Berthélaine, Le. 2012. The Work of Art in the Digital Age: The Painting and Pixel - an essay. Denmark: Books on Demand.

Hakim, Arfial Arsad. 1987. Nirmana Dwi Matra. Surakarta: UNS Press.

Mada Sanjaya. 2016. Robot Cerdas Berbasis Speech Recognition Menggunakan Matlab Dan Arduino. Yogyakarta: Penerbit Andi.

Nooryan Bahari. 2008. Kritik Seni Wacana Apresiasi dan Kreasi. Pustaka Pelajar. Yogyakarta.

P Mulyadi. 2000. Pengetahuan Seni. Surakarta: Mandar Maju.

Suranto Aw. 2010. Komunikasi Sosial Budaya. Yogyakarta: Graha IImu.

Yudrik Jahja. 2011. Psikologi Perkembangan. Jakarta: Prenadamadia Group 